\title{
HUBUNGAN ANTARA HARAPAN DAN STRES ORANG TUA YANG MEMILIKI ANAK DENGAN AUTISME
}

\author{
Grace Kurniadi $^{1}$, Ediasri Toto Atmodiwirjo ${ }^{2}$, Naomi Soetikno ${ }^{3}$ \\ ${ }^{1}$ Program Studi Magister Psikologi, Universitas Tarumanagara, Jakarta \\ Email: grace.717171002@stu.untar.ac.id \\ ${ }^{2}$ Fakultas Psikologi, Universitas Tarumanagara, Jakarta \\ Email: ediasri@gmail.com \\ ${ }^{3}$ Fakultas Psikologi, Universitas Tarumanagara, Jakarta \\ Email: naomis@fpsi.untar.ac.id
}

Masuk : 02-05-2019, revisi: 11-09-2019, diterima untuk diterbitkan : 26-11-2019

\begin{abstract}
ABSTRAK
Autisme merupakan gangguan perkembangan yang ditandai dengan gangguan sosial perilaku dan minat yang terbatas. Setiap orang tua yang mempunyai anak, memiliki harapan yang indah dan baik untuk anaknya. Diagnosis autisme akan kondisi anak menyebabkan stres pada orang tua. Stres ini menyebabkan harapan orang tua berubah. Penelitian ini bertujuan untuk mencari korelasi antara harapan dan stres orang tua yang memiliki anak dengan autisme. Karakteristik partisipan ini adalah orang tua yang memiliki anak berusia 3-16 tahun. Anak sudah didiagnosa autisme oleh dokter atau psikolog ataupun psikiater. Partisipan yang mengisi alat ukur penelitian ini sebanyak 69 orang. Alat ukur yang digunakan untuk mengukur harapan adalah adult dispotitional hope scale (ADHS), sementara alat ukur yang digunakan untuk mengukur stres orang tua adalah parental stress scale (PSS). Metode penelitian yang digunakan adalah metode penelitian kuantitatif korelasional dengan teknik pengambilan sampel yaitu purposive sampling. Analisis data menggunakan uji korelasi dengan perangkat lunak SPSS versi ke 23. Uji korelasi yang dilakukan menunjukkan korelasi negatif yang lemah antara harapan dan stres orang tua $(r=-.244$, $\mathrm{n}=69, p=.043$ ). Hal ini menunjukkan jika stres orang tua tinggi, maka harapan itu rendah. Sebaliknya jika harapan tinggi, stres orang tua rendah. Orang tua diharapkan untuk membuat harapan yang realistis serta mengelola stres yang dapat memengaruhi kondisi psikologisnya.
\end{abstract}

Kata kunci: harapan, stres orang tua, autisme

\section{ABSTRACT}

Autism is a developmental disorder characterized by impaired social behavior and limited interests. Every parent with children, hopes for the best for their children. If their children are diagnosed with autism, this will cause stress in parents. This stress causes the hope of parents to change. This study aims to find a correlation between hope and stress of parents who have children with autism. The characteristics of the participants are parents who have children aged 3-16 years. The child has been diagnosed with autism by a doctor, or psychologist, or psychiatrist. Participants who filled out the measurement tools of this study were 69 people. The measuring instrument used to measure expectations is the adult dispotitional hope scale (ADHS), while the measuring instrument used to measure parental stress is the parental stress scale (PSS). The research method used is quantitative correlational research method with purposive sampling technique. Data analysis was a correlation test using SPSS software version 23. The correlation test conducted showed a weak negative correlation between expectations and stress of parents $(r=-.244, n=69, p=.043)$. This shows that if parental stress is high, then hope is low. Conversely, if hope is high, parental stress is low. Parents are expected to have realistic hope and manage stress that can affect their psychological condition.

Keywords: hope, parental stress, autism

\section{PENDAHULUAN}

\section{Latar Belakang}

Berdasarkan Kementerian Pendidikan dan Kebudayaan (Kemdikbud) menyatakan bahwa jumlah anak berkebutuhan khusus (ABK) di Indonesia mencapai 1.554.184 anak dengan 330.764 $(21,42 \%)$ berada pada rentang usia 5-18 tahun ("Mengintip sekolah," 2015). Sementara data statistik yang ditunjukkan oleh Survei Penduduk Antar Sensus (SUPAS) 2015 memperlihatkan 
terdapat 8,56 persen penduduk yang memiliki disabilitas. Cakupan disabilitas tersebut adalah kesulitan melihat, mendengar, menggunakan tangan serta jari, mengingat/berkonsentrasi, gangguan perilaku/emosional, berbicara, serta mengurus diri sendiri (Badan Pusat Statistik, 2015).

Data dari Center for Disease Control and Prevention (CDC, 2018) menunjukkan bahwa 1 dari 59 anak-anak didiagnosis Gangguan Spektrum Autisme (Autism Spectrum Disorder/ASD) dengan sampel pada tahun 2014; dimulai pada usia 8 tahun pada 11 komunitas Amerika Serikat di jaringan The Autism and Developmental Disabilities Monitoring (ADDM). Jenis ABK yang paling banyak dialami di seluruh dunia salah satunya adalah autisme. Data statistik ABK di Indonesia belum akurat dan akan terus bertambah jumlahnya jika dilihat dari temuan global maupun kondisi yang mengemuka di tanah air (Harian Nasional, 2018). Di Indonesia, sumber resmi yang menunjukkan jumlah anak dengan autisme sangat terbatas. Satu-satunya studi mengenai jumlah autisme di Indonesia dilakukan tahun 1992 oleh Wignyosumarto, Mukhlas, dan Shirataki di Yogyakarta. Temuan menunjukkan bahwa jumlah autisme dari kelahiran Juni 1984 sampai Mei 1991 adalah 12 per 10000 (Wignyosumarto, Mukhlas, \& Shirataki, 1992).

Autisme merupakan gangguan perkembangan yang ditandai dengan gangguan komunikasi sosial dan perilaku, serta minat dan kegiatan yang terbatas. Diagnosis autisme didasarkan pada gejala perilaku dan sejarah perkembangan yang muncul (Klinger, Dawson, Barnes, Crisler, 2014). Berdasarkan Diagnostic and Statistical Manual of Mental Disorders-5 (DSM 5), diagnosis autisme tidak lagi memisahkan menjadi satu per satu gangguan seperti sindrom asperger, gangguan autistik, gangguan disintegratif masa kanak-kanak dan pervasive developmental disorder not otherwise specified (PDD-NOS), melainkan menjadi sebuah spektrum yang menunjukkan sangat beragamnya intensitas dan gejala pada setiap individu. Oleh sebab itu, autisme disebut sebagai gangguan spektrum (Bonnice, 2004/2009).

Perilaku anak penyandang autisme yang aneh dan berbeda dari anak- anak pada umumnya, membuatnya sering terkucil dan dianggap seperti orang dengan gangguan kejiwaan (Mawardi \& Dewi, 2018). Perilaku aneh seperti mengulang kata tanpa melakukan percakapan dua arah, tertawa ataupun menangis tanpa sebab, memutar-mutar objek selama beberapa jam, terobsesi terhadap benda tertentu, mengibaskan tangan (flapping hand), dan lebih memilih menyendiri ataupun mengasingkan diri (Bonnice, 2004/2009).

Pada saat pertama orang tua mendapat diagnosis autisme kepada anaknya, hal ini dapat menjadi masa tersulit dan paling membebani. Kondisi ini dapat memengaruhi persepsi tentang harapan dan kemampuan di masa depan untuk mengelola gangguan autisme (Mulligan, MacCulloch, Good, \& Nicholas, 2012). Seorang dokter spesialis kesehatan jiwa dan konsultan psikiatri anak remaja RS Pondok Indah Group, dr Ika Widyawati, SpKJ mengatakan ketika orang tua mendapat diagnosis autisme pada anak, hal tersebut akan membuat orang tua terkejut, marah, sedih, merasa tidak ada harapan serta merasa bersalah (Handayani, 2016).

Bonis (2016) merangkum dari beberapa peneliti bahwa reaksi ataupun respon orang tua saat mendapat diagnosis, bervariasi dari tingkat keparahan yang muncul dan munculnya kebingungan serta penolakan, juga keraguan dalam pengambilan keputusan. Mulligan et al. (2012) merangkum beberapa reaksi orang tua saat menerima diagnosis antara lain seperti perasaan terkejut, lega, takut, sedih, marah, mengisolasi diri, dan ketidakpastian setelah menerima diagnosis. Rasa malu, bersalah, menyalahkan diri sendiri, serta menolak untuk percaya ataupun menerima kenyataan diagnosis tersebut juga dialami oleh sebagian orang tua. 
Harapan orang tua berubah ketika mendapatkan diagnosis autisme pada anak ataupun mengetahui kondisi fisik yang tidak sesuai dengan keinginan. Sementara harapan juga merupakan prediktor penting dan kuat dari penerimaan orang tua terhadap kondisi anak (Kausar, Jevne, \& Sobsey, 2003). Diagnosis ini juga dapat memengaruhi motivasi orang tua untuk mencari dan terlibat dalam penanganan anak terhadap salah satu karakteristik autisme yaitu kekurangan dalam interaksi sosial dan komunikasi (Chu, Mohd Normal, McConnell, Tan, \& Joginder Singh, 2018).

Anak dengan autisme membuat orang tua mengkhawatirkan masa depan anak, serta membuat orang tua memiliki harapan yang rendah dan keputusasaan yang lebih tinggi untuk anak mereka (Wong \& Heriot, 2006; Neff \& Faso, 2015). Fernandez dan Arcia (2004) mengatakan bahwa orang tua juga secara tidak rasional menyalahkan diri sendiri karena menyebabkan anak mendapat autisme. Diagnosis tersebut menyebabkan stres dalam pengasuhan, depresi dan kecemasan (Neff \& Faso, 2015).

Saat stres hadir dalam diri orang tua, di sisi lain ada keinginan yang muncul dari orang tua untuk mendorongnya membuat perencanaan dalam mencapai tujuan yang menjadi harapan tersebut, dan akan mengusahakan perencanaan tersebut dapat terlaksana. Definisi harapan adalah mengharapkan yang terbaik di masa depan (Shogren, Niemiec, Tomasulo \& Khamsi, 2017) dan bekerja untuk mencapainya serta percaya bahwa masa depan yang baik adalah sesuatu yang bisa dicapai (Shrogen et al., 2017; Lee, Park, Hwang, 2016). Tanpa adanya harapan, orang tua tidak akan melakukan usaha untuk meningkatkan kemampuan berkomunikasi, bersosialisasi, serta mengurangi perilaku berulang yang muncul.

DePape dan Lindsay (2015) merangkum beberapa hasil penelitian yang menunjukkan beberapa harapan orang tua saat anak dewasa adalah bisa mandiri. Ibu Camelia Sulandi di Bangka selatan juga mengungkapkan harapannya yaitu anaknya dapat mandiri sebelum ajal menjemput. Selain kemandirian, Ibu Camelia Sulandi juga mengharapkan anaknya dapat berkomunikasi walaupun terbatas, serta adanya kontak mata dalam interaksi sosial (Dahnur, 2018).

Bonis (2016) merangkum dari beberapa penelitian, bahwa stres dimulai ketika orang tua berjuang untuk memahami masalah kesulitan berkomunikasi dan perilaku yang membahayakan anak sendiri serta lingkungannya. Neece, Shulamite, dan Baker (dalam Woodman, 2014) menunjukkan bahwa orang tua dengan anak yang memiliki gangguan perkembangan (developmental disabilities) mempunyai tingkat stres yang lebih tinggi dibandingkan tingkat stres rata-rata. Faktor lain yang dapat menyebabkan stres dapat berasal dari faktor patologis ataupun stresor dari lingkungan (Hayes \& Watson, 2013; Louie, Cromer, \& Berry, 2017). Sementara penyebab stres yang berasal dari anak adalah sifat anak, perbedaan individu anak, dan ada atau tidaknya gangguan perkembangan. Anak dengan temperamen sulit juga menjadi tantangan bagi orang tua, karena anak sangat reaktif, kurang fleksibel dan tidak mudah beradaptasi (Louie et al., 2017).

Kehadiran masalah perilaku anak diasosiasikan dengan meningkatnya stres orang tua. Orang tua anak penyandang autisme sering mengalami tingginya tingkat stres, perasaan terisolasi dan stigma (Mulligan et al., 2012). Stigma negatif pada autisme juga memperparah stres orang tua (Bonis, 2016). Stres orang tua yang meningkat di masa balita hingga remaja dapat menciptakan lingkungan keluarga yang kacau juga berdampak terhadap perilaku anak (Louie et al., 2017). Bonis (2016) merangkum dari berbagai penelitian bahwa orang tua dengan tingkat pendidikan dan sosio ekonomi yang tinggi, dapat mengenali pola perkembangan yang tidak biasa dan bisa 
mencari bantuan profesional. Orang tua juga dapat menghabiskan beberapa tahun dari satu tempat layanan kesehatan ke tempat lainnya hanya untuk mencari jawaban terkait dengan terlambatnya perkembangan serta perilaku yang aneh, serta membahayakan diri sendiri dan lingkungan.

Penelitian ini penting dilakukan untuk mengetahui hubungan antara harapan dan stres orang tua yang memiliki anak dengan autisme, mengingat di Indonesia belum ada yang meneliti secara khusus mengenai kedua variabel ini.

\section{Rumusan Masalah}

Rumusan masalah dalam penelitian ini adalah "Apakah terdapat hubungan antara harapan dan stres orang tua yang memiliki anak dengan autisme?".

\section{METODE PENELITIAN}

\section{Partisipan}

Karakteristik partisipan yang akan digunakan adalah orang tua yang mempunyai anak berusia 316 tahun yang sudah mendapat diagnosis autisme dari dokter anak/psikiatri anak/ psikolog. Orang tua merupakan orang tua kandung anak dan mengetahui kondisi anak dan tinggal bersama anak.

Teknik pengambilan data yang digunakan dalam penelitian ini adalah purposive sampling. Tujuan utama purposive sampling adalah fokus pada karakteristik tertentu dari suatu populasi. Penelitian ini dilakukan di tempat tertentu seperti sekolah dan klinik. Jumlah data yang direncanakan adalah 80 partisipan, namun data yang didapatkan berjumlah 69 partisipan. Hal ini disebabkan belum terkumpulnya data dari beberapa klinik ataupun sekolah.

\section{Prosedur penelitian}

Sebelum pengambilan data dilakukan, hal yang pertama adalah mendapatkan alat ukur Parental Stress Scale (PSS) dan Adult Dispositional Hope Scale (ADHS) terlebih dahulu. Setelah alat ukur tersebut didapatkan, penulis meminta ijin kepada pencipta alat ukur tersebut untuk keperluan alih bahasa dan adaptasi alat ukur. Selama menunggu hasil pengalihbahasaan alat ukur, dilakukan juga pencarian institusi yang menaungi calon partisipan yang sesuai dengan karakteristik partisipan penelitian. Sesudah mendapatkan institusi tersebut, peneliti mengurus perizinan dan menjelaskan mengenai penelitian ini pada institusi terkait.

Setelah selesainya alih bahasa, penulis menggabungkan ketiga alat ukur tersebut dalam satu kuesioner dan menyusun demografi yang akan ditanyakan pada orang tua sebagai partisipan. Dalam satu kuesioner tersebut, tidak akan dicantumkan nama alat ukur dan akan dipisah per bagian. Tujuan penggabungan alat ukur dalam satu kuesioner ini adalah meminimalkan kelalaian orang tua dalam mengisi ketiga alat ukur tersebut.

Penulis kemudian melakuan penilaian ahli (expert judgement) bersama dosen pembimbing dan dosen ahli lainnya. Setelah mendapatkan persetujuan dari ketiga ahli dalam kegiatan expert judgement, penulis merevisi dan memperbanyak kuesioner tersebut untuk uji coba dan uji keterbacaan pada orang tua. Hasil uji coba tersebut kemudian diolah oleh peneliti dengan menggunakan perangkat lunak SPSS versi ke 23. 
Kemudian penulis mendiskusikan hasil uji coba dengan pembimbing. Setelah pembimbing menyetujui, penulis merevisi kembali dan memperbanyak kuesioner tersebut. Sesudah persiapan selesai, penulis menyebar kuesioner tersebut ke tempat yang sudah mendapat izin. Penulis juga memberikan lembar persetujuan (informed consent) pada partisipan sebelum mengisi kuesioner serta bertujuan untuk menjaga kode etik psikologi terkait dengan kerahasiaan data dalam penelitian yang akan dilakukan.

\section{Instrumen penelitian}

\section{Adult Dispositional Hope Scale}

Alar ukur yang digunakan untuk mengukur harapan adalah Adult Dispositional Hope Scale. Adult Dispositional Hope Scale (ADHS) atau disebut dengan Adult Hope Scale (AHS). Alat ukur AHS ini dikembangkan oleh C.R.Snyder et al. (1991). Alat ukur ini bertujuan untuk mengukur tingkat harapan partisipan. ADHS ini terdiri dari 12 item dengan 4 item agency, 4 item pathways, 4 lainnya merupakan distraksi. Alat ukur ini menggunakan skala likert 4 poin dengan $1=$ pasti salah, 2=Agak Salah, 3=Agak benar, 4= Pasti benar.

Alat ukur ini dapat dikerjakan oleh individu berusia lebih dari 15 tahun. Skor harapan didapatkan dengan menjumlahkan item agency dan pathway. Total skor skala harapan bervariasi dari minimal 8 hingga 32, di saat dimensi agency dan pathway memiliki nilai skor minimum 4 dan maksimum 32 yang merefleksikan tingginya level harapan (Snyder et al., 1991). Contoh butir item ADHS pada dimensi agency adalah I energetically pursue my goals. Contoh butir item ADHS pada dimensi pathway adalah I can think of many ways to get out of a jam.

Alat ukur ini memiliki validitas yang cukup baik, dengan nilai Cronbach's alpha yang bervariasi dari .74 hingga .84 untuk skor total keseluruhan. Untuk subskala agency, menghasilkan nilai Cronbach's alpha dengan rentang .71 hingga .76; sementara subskala pathway, menghasilkan nilai Cronbach's alpha dengan rentang .63 hingga .80 .

\section{Parental Stress Scale}

Alat ukur yang digunakan untuk mengukur parenting stress adalah the Parental stress scale (PSS). Alat ukur PSS pertama kali dikembangkan oleh Judy O. Berry dan Warren H Jones pada tahun 1995. PSS merupakan alat ukur parent self-report.

Alat ukur PSS mempunyai 18 item yang mengukur aspek positif dan negatif dari pengasuhan serta mengukur tingkat stres yang dialami oleh orang tua. Berry dan Jones (1995) merangkum dua tema/aspek dari Belsky et al., yaitu positive themes of parenthood (emotional benefits, selfenrichment, personal development) dan negative components (tuntutan sumber daya, opportunity cost dan restrictions).

Cara menjawab alat ukur ini menggunakan skala likert 5 poin dengan $1=$ sangat tidak setuju, $2=$ tidak Setuju, 3= ragu-ragu, 4= setuju, 5= sangat setuju. Ada 8 buah butir item positif yang penilaiannya dibalik, sehingga ada kemungkinan skor total dapat mencapai 18-90. Semakin tinggi skor, menunjukkan tingginya stres. Contoh butir item PSS pada dimensi positive themes of parenthood adalah I find my children enjoyable, I am happy in my role as parent. Contoh butir item PSS pada dimensi negative themes adalah having children leaves little time and flexibility in my life, it is difficult to balance different responsibilities because of my children.

Alat ukur PSS mempunyai reliabilitas internal yang memadai $(\alpha=.83)$ dan hasil test-retest reliability dengan angka .81 . Validitas konvergen mempunyai nilai yang cukup memuaskan 
apabila dibandingkan dengan skor nilai total parenting stress index dengan nilai $0.75, \mathrm{p}<.01$. (Berry \& Jones, 1995).

\section{Teknik pengolahan data}

Pengolahan data penelitian ini dengan menggunakan uji korelasional dengan perangkat lunak SPSS 23.

\section{HASIL DAN PEMBAHASAN}

\section{Gambaran hasil alat ukur}

Pada bagian ini akan dibahas mengenai gambaran skor harapan dan stres orang tua serta uji korelasi. Pada Tabel 1. menunjukkan rentang skor harapan dan stres. Berdasarkan data yang didapatkan, rata-rata skor harapan keseluruhan dari 69 orang adalah 26,51 dengan skor harapan yang paling kecil yaitu 16 dan paling tinggi adalah 32. Berdasarkan data yang didapatkan, ratarata skor stres keseluruhan dari 69 orang adalah 28,39 dengan rentang stres yang paling kecil yaitu 20 sampai yang paling tinggi yaitu 40. Lebih jelasnya dapat dilihat pada Tabel 1.

Tabel 1

Gambaran hasil alat ukur

\begin{tabular}{cc|cc}
\hline Harapan & Skor & Stress & Skor \\
\hline Mean & 26,51 & Mean & 28,39 \\
Median & 27,00 & Median & 27,00 \\
Standard deviation & 3,18 & Standard deviation & 6,67 \\
Minimum & 16 & Minimum & 20 \\
Maximum & 32 & Maximum & 40 \\
\hline
\end{tabular}

Pada Tabel 2. Menunjukkan hasil korelasi harapan dengan stres orang tua. Hasil menunjukkan ada korelasi negatif yang lemah antara harapan dan stres orang tua $(r=-.244, \mathrm{n}=69, p=.043)$.

Tabel 2

Uji korelasi harapan dan stres orang tua

\begin{tabular}{lc}
\hline & \multicolumn{1}{c}{ Total skor harapan } \\
\cline { 2 - 2 } Total skor stres orang tua &,$- 244^{*}$ \\
Nilai signifikansi &, 043 \\
\hline *. Correlation is significant at the 0.05 level (2-tailed).
\end{tabular}

Berdasarkan data yang didapatkan, meski mempunyai anak dengan autisme, orang tua masih mempunyai harapan. Tingkat skor rata-rata stres orang tua terbilang tidak terlalu tinggi ataupun rendah. Hasil menunjukkan bahwa terdapat korelasi negatif yang lemah antara harapan dan stres orang tua. Hal ini menunjukkan bahwa semakin tinggi stres, maka akan semakin rendah harapan orang tua. Jika stres semakin rendah, harapan orang tua akan semakin tinggi.

Hal ini bertolak belakang dengan penelitian Wong \& Heriot (2006) yang menunjukkan bahwa adanya korelasi negatif yang kuat antara vicarious hope dan vicarious despair dengan nilai $r=-$ .84. Hasil korelasi yang didapatkan oleh Wong \& Heriot (2006) menggunakan sampel orang tua yang memiliki anak dengan autisme, anak dengan demensia (childhood dementia), dan pemilihan acak dari sampel normatif. 


\section{KESIMPULAN DAN SARAN}

Hasil pengolahan data menunjukkan korelasi negatif yang lemah antara harapan dan stres orang tua $(r=-.244, \mathrm{n}=69, p=.043)$.

Pada saat orang tua menerima diagnosis terhadap anak, mereka berharap memiliki anak yang normal. Orang tua yang memiliki anak dengan autisme juga merasa tidak pasti terhadap prognosis dan ketepatan diagnosis (Wong \& Heriot, 2006). Wong dan Heriot (2006) mengatakan beberapa orang tua berharap dengan positif akan masa depan anaknya, meskipun masih memegang keraguan akan kemampuan anak dalam mencapainya.

Saran pada penelitian selanjutnya yang ingin melihat stres dan harapan orang tua yang memiliki anak dengan anak autisme dapat menambah jumlah partisipan, serta menambah metode penelitian kualitatif untuk memperkaya hasil penelitian. Metode kualitatif dilakukan untuk menggali hal-hal yang menjadi harapan orang tua serta hal-hal yang membuat orang tua stres, selain diagnosis autisme pada anak. Penelitian selanjutnya diharapkan untuk mendapatkan data tingkat keparahan autisme, data demografis seperti suku, agama, pekerjaan, dan penghasilan. Hal ini diperkirakan dapat memengaruhi tingkat stres serta harapan orang tua. Penelitian ini diharapkan dapat memberikan gambaran harapan dan stres orang tua yang memiliki anak dengan autisme. Orang tua juga disarankan untuk membuat harapan yang realistis dan mengelola sumber stres yang memengaruhi kondisi psikologisnya.

\section{Ucapan Terima Kasih}

Ucapan terima kasih peneliti sampaikan kepada seluruh pihak universitas yang telah mengizinkan peneliti untuk melakukan pengambilan data. Lebih khususnya kepada seluruh partisipan yang telah bersedia meluangkan waktu dan telah bersedia untuk membantu penelitian ini melalui pengisian kuisioner, dari lubuk hati yang paling dalam peneliti ucapkan terima kasih.

\section{REFERENSI}

Badan Pusat Statistik. (2016). Profil penduduk Indonesia hasil SUPAS 2015. Jakarta: Author. Diakses dari https://media.neliti.com/media/publications/48298-ID-profil-pendudukindonesia-hasil-supas-2015.pdf pada tanggal 10 September 2018.

Berry, J. O., \& Jones, W. H. (1995). The parental stress scale: Initial psychometric evidence. Journal of Social and Personal Relationships, 12(3), 463-472. https://doi.org/10.1177/0265407595123009

Bonis, S. (2016). Stress and parents of children with autism: A review of literature. Issues in Mental Health Nursing, 37(3), 153-163. https://doi.org/10.3109/01612840.2015.1116030

Bonnice, S. 2004. The hidden child: Youth with autism (Ronawan, M. A. \& Setiadji, I., Trans.). Broomall, Pennsylvania: Mason Crest Publishers.

Center for Disease Control and Prevention . (2018). Autism data visualization tool. Diunduh dari https://www.cdc.gov/ncbddd/autism/data/index.html pada tanggal 13 April 2019.

Chu, S. Y., Mohd Normal, S. N. S. A. binti, McConnell, G. E., Tan, J. S., \& Joginder Singh, S. K. D. (2018). Challenges faced by parents of children with autism spectrum disorder in Malaysia. Speech, Language Hearing, 1-11. https://doi.org/10.1080/2050571X.2018.1548678

Dahnur, H. (2018, Mei 3). Sebelum mati saya ingin melihat anak autis bisa mandiri. Kompas Online. Diakses dari https://regional.kompas.com pada tanggal 24 Maret 2019. 
DePape, A. M., \& Lindsay, S. (2015). Parents' experiences of caring for a child with autism spectrum disorder. Qualitative Health Research, 25(4), 569-583. https://doi.org/10.1177/1049732314552455

Faso, D. J., Neal-Beevers, A. R., \& Carlson, C. L. (2013). Vicarious futurity, hope, and wellbeing in parents of children with autism spectrum disorder. Research in Autism Spectrum Disorders, 7(2), 288-297. https://doi.org/10.1016/j.rasd.2012.08.014

Fernández, M. C., \& Arcia, E. (2004). Disruptive Behaviors and Maternal Responsibility: A Complex Portrait of Stigma, Self-Blame, and Other Reactions. Hispanic Journal of Behavioral Sciences, 26(3), 356-372.doi:10.1177/0739986304267208

Handayani, I. (2016, April 24). Tangani autisme sejak dini. Investor Daily. Diakses dari http://id.beritasatu.com pada tanggal 29 September 2018.

Hayes, S. A., \& Watson, S. L. (2013). The impact of parenting stress: A meta-analysis of studies comparing the experience of parenting stress in parents of children with and without autism spectrum disorder. Journal of Autism and Developmental Disorders, 43(3), 62942. Doi:http://dx.doi.org/10.1007/s10803-012-1604-y

Kausar, S., Jevne, R. F., \& Sobsey, D. (2003). Hope in families of children with developmental disabilities. Journal on Developmental Disabilities, 10(1), 35-46.

Klinger, L.G., Dawson, G., Barnes, K., \& Crisler, M. (2014). Autism spectrum disorder. In E. J. Mash \& R. A. Barkley (Ed.), Child psychopathology (3rd ed.) (pp 531-572). New York, United States: Guilford Publications

Lee, C. S., Park, S. U., \& Hwang, Y. K. (2016). The structural relationship between mother's parenting stress and child's well-being: The mediating effects of mother's growth mindset and hope. Indian Journal of Science and Technology, 9(36). https://doi.org/10.17485/ijst/2016/v9i36/102702

Louie, A. D., Cromer, L. D., \& Berry, J. O. (2017). Assessing parenting stress: Review of the use and interpretation of the parental stress scale. The Family Journal, 25(4), 359-367. https://doi.org/10.1177/1066480717731347

Mawardi, I. \& Dewi, J.R. (2017, Desember 7). Fenomena orang gila: Sebagian masyarakat Indonesia masih menganggap pengidap autisme sama dengan orang gila. Tribun Jabar. Diunduh dari http://jabar.tribunnews.com pada tanggal 15 September 2018.

Mulligan, J., MacCulloch, R., Good, B., \& Nicholas, D. B. (2012). Transparency, hope, and empowerment: A model for partnering with parents of a child with autism spectrum disorder at diagnosis and beyond. Social Work in Mental Health, 10(4), 311-330. https://doi.org/10.1080/15332985.2012.664487

Neff, K. D., \& Faso, D. J. (2015). Self-compassion and well-being in parents of children with autism. Mindfulness, 6(4), 938-947. https://doi.org/10.1007/s12671-014-0359-2

Shogren, K.A., Niemiec, R.M., Tomasulo,D. \& Khamsi, S. (2017). Character strength. In Shogren, K. A., Wehmeyer, M. L., \& Singh, N. N. (Eds.) Handbook of Positive Psychology in Intellectual and Developmental Disabilities. Cham, Switzerland: Springer International Publishing. https://doi.org/10.1007/978-3-319-59066-0

Snyder, C. R., Harris, C., Anderson, J. R., Holleran, S. A., Irving, L. M., \& Sigmon, S. X. (1991). The will and the ways: Development and validation of an individual-differences measure of hope. Journal of Personality and Social Psychology, 60(4), 570-585.

Tamba, A. \& Triyudha, A. (2018, April 2). Tren penderita autisme meningkat. Harian Nasional. Diunduh dari http://www.harnas.co pada tanggal 8 September 2018.

Wignyosumarto S., Mukhlas M., Shirataki S. Epidemiological and clinical study of autistic children in Yogyakarta, Indonesia. Kobe J Med Sci. 1992 Feb;38(1) 1-19.

Woodman, A. C. (2014). Trajectories of stress among parents of children with disabilities: A dyadic analysis. Family Relations, 63(1), 39-54. 
Wong, M. G., \& Heriot, S. A. (2006). Vicarious Futurity in Autism and Childhood Dementia. Journal of Autism and Developmental Disorders, 37(10), 18331841.doi:10.1007/s10803-006-0317-5 